University of Nebraska - Lincoln

DigitalCommons@University of Nebraska - Lincoln

1982

\title{
THE PLANT PATHOGENIC CORYNEBACTERIA
}

Anne K. Vidaver

Follow this and additional works at: https://digitalcommons.unl.edu/plantpathpapers

Part of the Other Plant Sciences Commons, Plant Biology Commons, and the Plant Pathology Commons

This Article is brought to you for free and open access by the Plant Pathology Department at DigitalCommons@University of Nebraska - Lincoln. It has been accepted for inclusion in Papers in Plant Pathology by an authorized administrator of DigitalCommons@University of Nebraska - Lincoln. 
Annual Review of Microbiology

Vol. 36, 1982

Ann. Rev. Microbiol. 1982. 36:495-517

Copyright $\odot 1982$ by Annual Reviews Inc. All rights reserved

\section{THE PLANT PATHOGENIC CORYNEBACTERIA}

Anne K. Vidaver

Department of Plant Pathology, University of Nebraska, Lincoln, Nebraska 68583-0722

\section{CONTENTS}

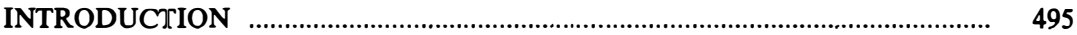

TAXONOMY …….................................................................................................... 496

HABITATS, ISOLATION, CULTIVATION, AND GROWTH ............................ 500

PATHOGENICITY FACTORS ….................................................................... 503

THE ROLE OF NEMATODES IN PLANT DISEASES ASSOCIATED WITH

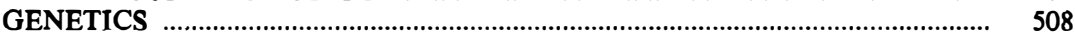

BACTERIOPHAGES AND BACTERIOCINS …............................................ 509

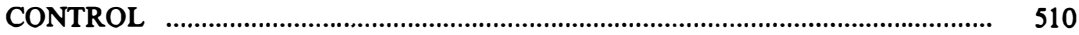

CONCLUDING REMARKS AND PROSPECTS FOR THE FUTURE ................ 512

\section{INTRODUCTION}

The plant pathogenic corynebacteria are a fascinating group of bacteria that produce effects as diverse as any in the microbial world, ranging from wilts to abnormal growths. Several new pathogens have been discovered since this group was reviewed by Jensen (75), Starr (157), and Lelliott (96). Most subsequent reviews have dealt with taxonomy. The areas covered in this review necessarily reflect my biases and limitations. However, this review attempts to be comprehensive in some areas, and it calls attention to other areas that would benefit from more detailed investigation.

This review is limited to corynebacteria whose association with plants is confirmed and to other bacteria for which taxonomic work indicates association or placement with known corynebacteria. Incompletely identified corynebacteria have been reported and are not discussed here, such as the 
causal agents of brown-stem disease of beans (185), stunting and other symptoms of soybeans $(42,114)$, cardamon blight (56), rotting yams (116), and carnation rot [mixed infection with Pseudomonas caryophylli (12)]. Two other plant-associated coryneforms are excluded: the cytokinin-producing bacteria isolated from pine seedling roots that might be saprophytic (79), and the specific coryneform that has been found in the leaf cavity of the fern Azolla caroliniana in its symbiotic association with the nitrogenfixing blue-green alga, Anabaena azollae (54), a phenomenon of unknown significance.

Some general properties of these bacteria should be noted. These are all Gram-positive, aerobic, pleomorphic rods (at some stage or condition of growth). In contrast to most Gram-positive bacteria, but like other coryneform bacteria [except Brevibacterium linens (51) and an unusual coryneform (2)], the plant pathogenic coryneforms lack teichoic acid in their cell walls $(38,51)$. Most of these bacteria can be seed borne (129) or are transmitted by insects (67), and they have a restricted natural host range. These bacteria are not considered soil, air, or water inhabitants, with the possible exception of Corynebacterium fascians $(41,104)$; their survival depends on association with plant material (141). The majority of the phytopathogenic corynebacteria produce systemic, rather than localized, infections; only $C$. fascians and the newly discovered bacterial wheat mosaic pathogen (14) are in the latter category. These two pathogens also do not require injury or wounding of plants to produce their effects, in contrast to the rest of the group in which wounding is the predominant (if not the only) form of entry into plants. Some of these properties are elaborated on below.

\section{TAXONOMY}

The bacteria in this group of plant pathogens present a continuing challenge at all levels of taxa placement. There have been more studies on the taxonomy of these bacteria in recent years than in any other area. Most of the data and the rationale for placement of these bacteria into different taxa have been recently reviewed $(15,40,42,77,83,155,181,187)$. Therefore, only some general comments are made to orient the reader.

At the highest taxonomic level, Stackebrandt et al (155) propose that most coryneforms (including single strains of two plant pathogenic species) and actinomycetes form at least five unnamed clusters (families) of a single order. They used comparative analysis of oligonucleotides in the ribosomal 16S RNA as a criterion of relatedness because it is generally agreed that -RNA is more conserved than are other nucleic acids. DNA : DNA hybridzation, for example, yields little information on genetic relationships of ipecies exhibiting homology values below $20 \%$ (154). 
Below the family level, the phytopathogens are currently retained within the genus Corynebacterium (30). Whether this is appropriate is a matter of considerable disagreement. The plant pathogens are in this genus because historically all aerobic, nonsporeforming, irregularly shaped Gram-positive rods (like $C$. diphtheriae) were assumed to be related $(75,82)$. However, recent studies show that all the plant-disease-associated coryneform bacteria, with the possible exception of $\boldsymbol{C}$. fascians, are significantly different from $C$. diphtheriae, particularly in chemical composition (84).

The plant pathogenic bacteria have a $\mathrm{G}+\mathrm{C}$ content of $65-76 \%$ compared to $52-60 \%$ for $C$. diphtheriae $(15,28,40,169)$. There are different diamino acids in the cell wall peptidoglycan of some species. These are L-lysine in C. ilicis and possibly in C. rathayi; diaminobutryic acid in the $C$. michiganense group, $C$. iranicum, and $C$. tritici; L-ornithine in the $C$. flac faciens group; and meso-diaminopimelic acid in $C$. fascians and the human pathogen $C$. diphtheriae $(24,84,125)$. Three of the plant pathogens were classified in a rare peptidoglycan group designated B2, based on cross linkages between peptide subunits and the presence on an inter-peptide bridge containing a D-diamino acid (138). In addition, examination of vitamin $\mathrm{K}$ and its derivatives (menaquinones) showed that only $C$. fascians has a menaquinone system with an 8-isoprene-unit side chain in common with $C$. diphtheriae; the remaining plant pathogens have major menaquinones of 9 or 10 isoprene units $(22-24,190)$. Phospholipid analyses also showed that only $C$. fascians shared phosphatidylethanolamine with $C$. diphtheriae and its relatives; other plant pathogenic corynebacteria lack this compound (88). There are also differences between $C$. diphtheriae and two phytopathogenic corynebacteria in their 16S rRNA sequences (155). Wall carbohydrate analyses (84) show differences in composition for different strains of the same species; such differences are therefore unlikely to be useful for taxonomic classification, but they may have significance in pathogenicity and other recognition phenomena. Cellular protein analyses by single-dimension polyacrylamide gel electrophoresis also show significant differences among certain plant pathogenic corynebacteria and the animalassociated $C$. bovis (15). The groupings suggested by Carlson \& Vidaver (15) are consistent with the most recent and extensive DNA : DNA hybridization studies, including plant pathogens (40). Collectively, then, the data show that the plant pathogens as a group are not closely related to $C$. diphtheriae and its relatives.

Differences among the coryneform bacteria led to several suggestions that the plant pathogenic corynebacteria be transferred into one or more genera by the 1950s (75) and most recently into Arthrobacter, Curtobacterium, Microbacterium, or Rhodococcus $(40,77,84,155)$. These conclusions are supported by some numerical taxonomy studies based on phenotypic prop- 
erties [Level 4 of microbial expression $(115)](9,32,76,103,185)$ and DNA :DNA hybridization (40). Dye \& Kemp (43), however, question the transfer of these bacteria into one or more of the suggested genera because of considerable homology among them in phenotypic properties; they suggest that these bacteria be retained in the genus Corynebacterium for the time being.

Thus, despite a growing and strongly supported view that Corynebacterium is not an appropriate repository for the plant pathogens, even proponents of change say that "much more information on a large number of strains is required before the creation of [other] genera can be contemplated" (83). Keddie (82) concluded that it is still convenient to use the term coryneform bacteria to define "a broad morphological group, sometimes imperfectly, but [it] does not imply relatedness within it." For purposes of this review, the plant pathogens are retained within the genus Corynebacterium.

Below the generic level, recent studies show that some currently described species (147) do not have sufficient differences among them to justify their recognition as distinct taxa at the species level $(15,40,43)$. There is disagreement, however, whether the differences found among them warrant taxon placement at the subspecific level (15) or at the infrasubspecific level of pathovars (43). The data of Carlson \& Vidaver (15) led them to formally propose the following new combinations: $C$. flaccumfaciens ssp. flaccumfaciens; $C$. flaccumfaciens ssp. poinsettiae; $C$. flaccumfaciens ssp.betae; $C$. flaccumfaciens ssp. oortii; $C$. michiganense ssp. michiganense; $C$. michiganense ssp. nebraskense; $C$. michiganense ssp. insidiosum; $C$. michiganense ssp. sepedonicum. A new taxon $C$. michiganense ssp. tessellarius was also proposed. ${ }^{1}$ Taxa that remained unchanged are $C$. fascians, $C$. ilicis, $C$. tritici, C.iranicum, and $C$. rathayi. This classification is generally consistent with the DNA : DNA hybridization data of Döpfer et al (40). Thus, it is my belief that this classification is the most useful at the present time and is likely to be accepted by plant pathologists and microbiologists; hence, it is used here.

There are occasional anomalies in reports of plant pathogenic corynebacterial species. C. ilicis, which causes a disease of holly, apparently has only been seen once $(99,100)$. Some of the corynebacteria classified with plant pathogens either have not been reported as plant pathogens [" $C$. mediolanum," (155)] or were reported once and are no longer available in known culture collections [" $C$. agropyri" and others (30)]. These species are not in the 1980 Approved Lists of Bacterial Names and consequently have no

\footnotetext{
${ }^{1}$ Hereafter, these names are abbreviated as $C$. $f$. ssp. flaccumfaciens, $C$. $f$. ssp. poinsettiae, $C$. $f$. ssp. betae, $C$. $f$. ssp. oortii, $C$. $m$. ssp. michiganense, $C$. $m$. ssp. insidiosum, $C$. $m$. ssp. sepedonicum, $C . m$. ssp. nebraskense, and $C . m$. ssp. tessellarius.
} 
standing in the literature. " $C$. agropyri," however, was recently isolated from a 37-year-old herbarium specimen (106a); its relationship to other plant pathogens can now be determined. $C$. rathayi and $C$. tritici were inadvertently left off the Approved Lists and have been revived (15) on the basis of differences between them and other species.

The classification of other plant-associated corynebacteria is not clear. Recent information on the sugarcane ratoon stunting bacterium $(33,98)$ suggests that this coryneform is similar to several known pathogens in having a high G+C (67-68\%) and diaminobutryate in the cell wall (M. J. Davis, personal communication). Kao et al (80), however, report $60 \%$ $\mathrm{G}+\mathrm{C}$ and both ornithine and lysine in the cell wall. It is not clear whether or not differences in methods and strains account for these discrepancies. And it will be of interest to know how a newly isolated coryneform associated with leaf scorch of grape (D. C. Gross, personal communication) is related to the other corynebacteria.

All coryneform pathogens except $C$. fascians are generally host specific under natural conditions (see Table 1), a fortuitous situation, as disease diagnosis and pathogen identification are virtually certain if the host is known (see 180,181 ). For relatively quick pathogenicity determinations, alternate hosts may be more convenient, e.g. eggplant can be used to test C. $m$. ssp. sepedonicum strains (see 29). There is some difficulty, however, in easily distinguishing the plant pathogens in culture independent of the host plant, but motility, pigmentation, colony morphology, and growth on triphenyl tetrazolium agar usually serve to distinguish the pathogens commonly found in the USA (180).

Morphological differences and mode of cell division are questionable criteria in the classification of corynebacteria, including plant pathogens $(82,155)$. For example, electron micrographs of $C$. rathayi cultivated in vitro can show a simple rod form whereas the same culture from plants shows pleomorphism characteristic of coryneform bacteria (6). It is by no means clear how one should decide which is correct or typical.

Colony pigmentation can be a useful aid in identification of plant pathogenic corynebacteria, but pigment analysis is of unproven value in classification. The majority of these bacteria are pigmented in shades of yellow or orange on complex media, but other colors are sometimes seen from freshly isolated material or after extensive cultivation $(52,160 ; R$. R. Carlson \& A. $\mathrm{K}$. Vidaver, unpublished results). The water-insoluble blue pigment indigoidine (89) can assist in identifying $C . m$ ssp. insidiosum when it is present. A water-soluble extracellular purple pigment can be produced by some strains of $C$. $f$. ssp. flaccumfaciens (143). The lipid-soluble pigments of coryneform bacteria have been recently reviewed (105); the plant pathogens $C$. $f$. ssp. poinsettiae, $C$. $m$. ssp. michiganense, and $C$. fascians all have 
carotenoids that appear to differ from one another. However, as no systematic studies of pigments have been reported, the utility of pigments in classification is still an open question.

Rapid and specific identification may be possible by two methods. Serological identification of specifc corynebacteria has produced contrasting results (see 34, 66, 136). It is not clear whether such results are due to the specific immunogen or strain, its age, condition or treatment prior to immunization (e.g. 19), or to variables in the techniques employed. It is clear that sera prepared against one pathogen can cross-react with taxonomically closely related and distantly related corynebacteria (e.g. 29, 34, 136). In view of the high degree of similarity among many of the plant corynebacteria $(15,43)$, such cross-reactions may be expected. For the ratoon stunting organism, however, specific antisera have been obtained (M. J. Davis, personal communication). The convenient, though less sensitive, latex-agglutination test (149) is currently being used as much as indirect fluorescent antibody techniques (34). There are differences of $10^{4}$ in the sensitivity of the indirect fluorescent antibody technique for rapid detection and presumptive identification of $C$. $m$. ssp. sepedonicum $(35,148)$, perhaps due partly to differences in sampling or concentration of antigen or antibody. The advent of monoclonal antibody techniques may allow for the preparation of specific antibodies for the corynebacteria. This would enable some of the problems in serological identification and specificity to be resolved in the near future. The second method, bacteriocin production, offers promise of specific and relatively rapid identification of the majority of strains and species of phytopathogenic corynebacteria (64), but confirmation is needed.

\section{HABITATS, ISOLATION, CULTIVATION, AND GROWTH}

Since this area was reviewed recently (181), only highlights are mentioned here. In general, the corynebacterial plant pathogens are studied because of their economically important associations with plants, including latent infections by $C$. $m$. ssp. sepedonicum $(7,29,70,150)$ and $C$. $f$. ssp. flaccumfaciens (170). Survival requires association with diseased plants or residue materials $(108,139,141)$. With the possible exception of $C$. fascians $(104$, 139), these bacteria are considered poor survivors in soil. This could be due to the action of other microorganisms, such as rhizobia, Bacillus, or Arthrobacter sp., which produce antibiotic-like substances in vitro $(62,69)$. Soil survival studies of corynebacteria can be criticized on several grounds: lack of inoculum quantitation, unspecified growth state of the inoculum, use of genetically unmarked bacteria [except one study of $C$. m. ssp. insidiosum (111)], indirect recovery using plants as bait, and ignorance of detection 
Table 1 Diseases caused by plant pathogenic corynebacteria

\begin{tabular}{|c|c|c|c|}
\hline Bacterium $^{\mathrm{a}}$ & Natural host & Predominant symptoms & References $b$ \\
\hline C. fascians & $\begin{array}{l}\text { General: annuals, } \\
\text { perennials }\end{array}$ & $\begin{array}{l}\text { Leaf, bulb distortion; bud } \\
\text { deformity; proliferation }\end{array}$ & 30,41 \\
\hline $\begin{array}{l}\text { C. flaccumfaciens } \\
\text { ssp. flaccumfaciens }\end{array}$ & Field bean & Wilt & 41 \\
\hline $\begin{array}{l}\text { C. flaccumfaciens } \\
\text { ssp. betae }\end{array}$ & Beet & Silvering of leaves; wilt & 30 \\
\hline $\begin{array}{l}\text { C. flaccumfaciens } \\
\text { ssp. oortii }\end{array}$ & Tulip & Leaf, bulb spot; wilt & 30 \\
\hline $\begin{array}{l}\text { C. flaccumfaciens } \\
\text { ssp. poinsettiae }\end{array}$ & Poinsettia & Leaf spot; wilt & 30 \\
\hline C. ilicis & American holly & Shoot, branch blight & 99 \\
\hline C. iranicum & Wheat & $\begin{array}{l}\text { Yellow slime of leaves, in- } \\
\text { florescences; leaf spots }\end{array}$ & 30 \\
\hline $\begin{array}{l}\text { C. michiganense } \\
\text { ssp. michiganense }\end{array}$ & Tomato pepper & Wilt, fruit spot & 41,160 \\
\hline $\begin{array}{l}\text { C. michiganense } \\
\text { ssp. insidiosum }\end{array}$ & Alfalfa & Wilt, stunting & 30,41 \\
\hline $\begin{array}{l}\text { C. michiganense } \\
\text { ssp. nebraskense }\end{array}$ & Corn & Wilt, leaf blight & $140,146 \mathrm{a}$ \\
\hline $\begin{array}{l}\text { C. michiganerise } \\
\text { ssp. sepedoricum }\end{array}$ & Potato & Wilt, tuber rot & $41,101,144$ \\
\hline $\begin{array}{l}\text { C. michiganense } \\
\text { ssp. tessellarius }\end{array}$ & Wheat & Leaf spot & 14 \\
\hline C. rathayi & $\begin{array}{l}\text { Cocksfoot grass, } \\
\text { annual ryegrass }\end{array}$ & $\begin{array}{l}\text { Yellow slime of leaves, } \\
\text { inflorescences }\end{array}$ & 10 \\
\hline C. tritici & Wheat & $\begin{array}{l}\text { Yellow slime of leaves, } \\
\text { inflorescences }\end{array}$ & 5,11 \\
\hline $\begin{array}{l}\text { Ratoon stunting } \\
\text { bacterium }\end{array}$ & Sugarcane & Stunting & 33 \\
\hline
\end{tabular}

a See text for classification rationale. Only bacteria currently in culture collections are listed.

$\mathrm{b}_{\mathrm{A}}$ current compilation of disease descriptions is not available; these references will enable interested readers to obtain representative descriptions. Commonwealth Mycological Institute descriptions (e.g. ref. 10,11) are available for many of these pathogens.

limits. All of these bacteria can be isolated from both infected and infested seed, tubers, or bulbs $(41,139,180$; Carlson \& Vidaver, unpublished results), particularly if material is obtained from areas of known infection. C. fascians can be difficult to isolate from leafy-galls (93) and bulbs (176) and may require enrichment through an intermediate host plant $(139,176)$. Epiphytic survival on, and natural infection of, weeds has been reported for C. $m$. spp. nebraskense (140), C. $f$. ssp. flaccumfaciens (see 141), and $C$. $m$. ssp. michiganense $(160 ; 171)$; whether or not weeds are hosts for the remaining pathogens is not known. At least some of these pathogens can 
survive in untreated water for many hours [C. rathayi, reported in Kuznetsov et al (91)] or even weeks [ $C$. $m$. spp. nebraskense (158)], suggesting that this may be a source of inoculum. Secondary sources of inoculum are less well studied. C. $m$. ssp. sepedonicum survives on the surfaces of potato handling equipment; this plays an important role in its epidemiology (e.g. $107,109)$. No airborne survival studies have been published, to my knowledge. Thus, for all practical purposes, infected seed, tubers, bulbs, and plants are the primary sources of inoculum and also are source material for isolation of the bacteria.

Growth of the phytopathogenic corynebacteria on complex media is relatively slow, ranging from about 3 days for visible colony formation of C. $f$. ssp. flaccumfaciens

of the fastidious ratoon stunting bacterium $(15,33,43,96,98)$ at optimal growth temperatures ranging from 23 to $28^{\circ} \mathrm{C}$. Such slow growth and the relative lack of selective media have hampered ecological studies (181). The selective media devised for C. m. ssp. nebraskense (63), C. m. ssp. sepedonicum (151), and C. m. ssp. michiganense (78) delay colony formation 1 or more days. An improved selective medium for $C$. $m$. ssp. sepedonicum and selective media for other corynebacteria are in the process of development (M. Sasser, personal communication). These are needed and should prove useful in determining the survival and spread of these bacteria in various habitats. Soil, air, and water sampling for pathogens should then be feasible; these potential avenues of spread have been virtually ignored by investigators because of the limitations of current isolation procedures in which the majority of saprophytic bacteria outnumber and outgrow the pathogens.

Nutritionally, not many advances have been made since Starr's (156) pioneering study of these bacteria. He found $C$. fascians strains to be least fastidious, requiring only thiamine as a growth factor, whereas thiamine, biotin, and pantothenate were required for growth of $C$. $f$. ssp. Alaccumfaciens and $C$. $f$. ssp. poinsettiae in a minimal salts, amino-acid medium. Thus, it is interesting that Keddie et al (85) found the same requirements needed by herbage isolates but not soil coryneform bacteria. For the related pathogens, $C$. $m$. ssp. michiganense, $C$. $m$. ssp. insidiosum, and $C . m$. ssp. sepedonicum, amino acids, thiamine, biotin, and nicotinic acid (niacin) were required (156). Lachance (94) confirmed these requirements for $C . m$. ssp. sepedonicum. In view of the close taxonomic relationship of these bacteria to $C$. $m$. ssp. nebraskense and $C$. $m$. ssp. tessellarius (15), it is not surprising that the same three growth factors were highly stimulatory (R. R. Carlson \& A. K. Vidaver, unpublished results) in a purified agar minimal salts medium (178).

Amino acid requirements for growth have been examined even more sparsely (see 30). L-Methoinine is required by $C$. $m$. ssp. sepedonicum (73), 
C. $m$. ssp. nebraskense, and C. $m$. ssp. tessellarius (R. R. Carlson \& A. K. Vidaver, unpublished results) and it is highly stimulatory for $C$. $f$. ssp. flaccumfaciens (130). In this regard, Owens \& Keddie (119) reported that the amino acid requirement of 23 out of 38 herbage coryneforms could be satisfied by L-methionine alone in a basal salts medium with vitamins and inorganic ritrogen. These results suggest a close relationship between these bacteria and the plant pathogens. It is also interesting that $0.3 \mathrm{mM}$ cystine and cysteine inhibited a strain of $C$. $m$. ssp. sepedonicum (73); unfortunately, potato tubers have not been found to contain these amino acids in such high concentration (73). L-Cysteine was also inhibitory for $C$. $f$. ssp. flaccumfaciens (130).

The only biochemical studies of metabolism in this group of bacteria deal with the examination of carbohydrate dissimilation. These are all aerobic organisms and oxidize glucose in conventional ways. Zagallo \& Wang (193), using radiorespirometric methods, showed that a single strain of $C$. tritici was metabolically similar to a strain of Arthrobacter globiformis in primarily using the Embden-Meyerhof-Parnas pathway, and to a lesser extent the hexose monophosphate pathway, whereas in a strain of $C . m$. ssp. sepedonicum both pathways appeared to be equally important in glucose dissimilation. There are also reports of a pentose cycle in $C . m$. ssp. michiganense, C. f. ssp. fiaccumfaciens,

(194). More data are needed on major metabolic pathways, both anabolic and catabolic, for other strains and species.

\section{PATHOGENICITY FACTORS}

Tbe phytopathogenic corynebacteria probably cause all or part of their pathogenic effects by the production of various metabolites, including "toxins," polysaccharides, hormones, and possibly enzymes $(31,122,163,181)$. More is known about the chemistry of such compounds than of their biosynthesis and modes of action.

The first reports of extracellular polysaccharides in phytopathogenic corynebacteria was by Gorin \& Spencer (59), who examined named strains (NCPPB) of $C$. $m$. ssp. michiganense, $C$. m. ssp. sepedonicum, $C . m$. ssp. insidiosum, C. fascians, $C$. f. ssp. flaccumfaciens,

The strains produced polysaccharides differing markedly in sugar content and composition. Subsequently, some of these compounds were shown to be large peptidyl glycans of about $2 \times 10^{4}$ to $5 \times 10^{6}$ daltons; those isolated from strains of the taxonomically related bacteria $C$. $m$. ssp. insidiosum (59, $131,132), C . m$. ssp. sepedonicum $(59,161)$, and $C$. m. ssp. michiganense $(127,128)$ could cause wilting of plants. According to Gorin \& Spencer (59), these compounds contained high concentrations (29-46\%) of fucose, al- 
though Strobel and associates, using unidentified strains, found little or no fucose in $C . m$. ssp. sepedonicum $(162,165)$ and differing quantities in $C$. $m$. ssp. insidiosum strains $(131,132)$. Fucosyltransferase activity, possibly involved in biosynthesis of the polysaccharide material, was reported in a culture of C. m. ssp. insidiosum (134).

The polysaccharide structure from a single strain of $C . m$. ssp. insidiosum appears to be a polymer of D-glucose, D-galactose, L-fucose, and pyruvic acid residues (60), whereas a $C . m$. ssp. sepedonicum polysaccharide was reported to consist largely of mannose, glucose, galactose, and 2-keto-3deoxygluconic acid (165). The latter results differ from those of Gorin \& Spencer (59), who found a preponderance of galactose, glucose, and fucose in NCPPB 9850. These nonspecific wilt-inducing macromolecules were all isolated from stationary phase cultures; compounds that produced similar wilting activity were isolated from plants infected by $C$. $\mathrm{m}$. ssp. sepedonicum $(153,162)$ and $C . m$. ssp. insidiosum $(132,153)$. Ultrastructural membrane and cell wall damage was reported by Strobel \& Hess (164) for cut tomato stems treated with $10 \mathrm{mg}$ of $C$. $m$. ssp. sepedonicum "toxin" per $\mathrm{ml}$ for $2 \mathrm{hr}$ and for potato stems sampled 4 to 5 weeks after inoculation with the same organism (71). Other workers have not detected any physiological (175) or ultrastructural (184) evidence of membrane damage in either alfalfa cuttings treated with low concentrations of $C$. $m$. ssp. insidiosum "toxin" (175) or in infected alfalfa plants (37) or infected tomato plants (184). In the Van Alfen \& Turner (175) study, as little as $2 \mu \mathrm{g}$ of toxin forced into the stem resulted in a marked (19\%) decrease in water conductance, and $200 \mu \mathrm{g} / \mathrm{ml}$ was effective in visible wilting. No evidence of mechanical plugging was detected either by conductivity studies (37) or by electron microscopy (184). There is rather convincing evidence that the only requirement for effectiveness in wilting is large size $(173,174)$. The claim by Strobel and associates (159) that the wilt toxin of $C$. $m$. spp. insidiosum can be used to differentiate susceptible and resistant alfalfa varieties has not been confirmed $(55,174)$. All the above considerations, and the numerous internal qualitative and quantitative inconsistencies detailed by Daly (31), make it difficult to have full confidence in the work of Strobel and associates (71, $127,128,131,132,134,159,161-164)$.

Electron microscopy showed that membrane damage to chloroplasts was the earliest detectable site of damage (D. W. Fulbright, personal communication) with the newly described, presumably nonvascular, wheat pathogen, $C$. $m$. ssp. tessellarius $(14,15)$. This observation is consistent with the appearance of irregular chlorotic spots characteristic of this leaf disease. Whether or not toxin is involved in this phenomenon remains to be determined.

Three corynebacterial pathogens, $C$. rathayi, $C$. tritici, and $C$. iranicum, secrete copious quantites of gums (apparently polysaccharides) onto infected 
leaves and developing seeds; $C$. rathayi $i$-infected plants can have toxicity to grazing animals, especially sheep (5).

The $C$. rathayi toxic factor(s) can be efficiently isolated from annual ryegrass (Lolium rigidum) galls that are induced by nematodes (see below) and colonized by bacteria (182). The toxic factor can be less efficiently isolated from inoculated ryegrass (Lolium multiflorum) endosperm tissue cultures (166). Stynes \& Petterson (166) suggested that the low concentration of toxin produced may be due to either the use of a nonoptimal grass species or a nonoptimal physical and chemical environment for the tissue culture: bacterium interaction. It is also possible that different strains of the bacterium could produce differing quantities of toxin. No toxin production was detected by the bacteria in vitro with any of 10 culture media, nor was toxin isolated from the culture media or uninoculated plant cell cultures (167). Thus, bacteria are required for toxin production. Whether the bacterium induces the plant to produce a toxic substance or vice versa is not yet clear. These studies show the possibilities not only of obtaining toxin in quantity and studying its biosynthesis under controlled conditions, but they also offer the potential of an in vitro assay for testing plant breeding material for resistance to the bacteria or toxin production.

Partially purified glycoplipid toxin fractions have been isolated from $C$. rathayi-infected plants (182); a minimum lethal dose for nursling rats was less than $5 \mu \mathrm{g}$ for six of eight fractions tested. The toxic gall material was purified by reverse-phase high performance liquid chromatography (HPLC) to yield a group of eight compounds; control extracts of normal rye grass seeds proved to be nontoxic and did not give any high performance liquid chromatography traces typical of the toxic mixture (182). (However, neither controls of nematode galls alone or toxin produced in tissue culture was reported.) All eight compounds were principally glycolipids. The two main toxin fractions, designated corynetoxin 3 and 4, contained 3-hydroxyheptadecanoic acid and heptadec-2-enoic acid, respectively, as principal components. Each also contained an amino sugar, suggested as glucosamine, and all eight compounds contained residues presumed to be either uracil or cytosine. In this regard it is of interest to note that the wilting material isolated by Pearson (124) for $C$. $m$. ssp. sepedonicum contained an estimated 10-30\% nucleic acid and was inactivated by DNase and RNase in combination (not tested separately). The role of the $C$. rathayi toxin in rye grass toxicity of animals seems firm; whether or not any of the toxic fractions have any effects on plants has not yet been reported.

Many questions remain as to the role of toxic antimetabolites in pathogenicity. It needs to be pointed out (192) that the majority of criteria used to evaluate the pathological significance of toxins, including symptom production, presence in plants, kinetics of production during disease devel- 
opment, and correlation of biosynthetic rate with virulence, are logical but inconclusive as primary lines of evidence. Genetic analyses are needed for definition of the role of toxins in disease (192). The same, of course, can be said for other pathogenicity factors.

The abnormal growth characteristics of leafy galls or fasciation (distortion of flowers or stems) associated with $C$. fascians infections are undoubtedly due to one or more of the plant hormones it can produce; this topic was recently reviewed (181). The relationship of hormone production to the presence of a "large plasmid" is tenous (106); its loss in one of four strains was correlated with loss of virulence. No association between pathogenicity and plasmid presence was detected in other strains (E. N. Lawson \& M. P. Starr, manuscript in preparation).

Evidence for enzymatic activity as a pathogenicity factor is indirect. Ultrastructural studies of tomato plants infected with $C$. $m$. ssp. michiganense showed plant cell wall degradation occurring before any visible symptoms (184). Both cellulytic and pectolytic enzymes were implicated in progressive breakdown of cell walls and middle lamella, respectively. Histochemical and fluorescence microscopy of naturally infected tomatoes showed middle lamella, rather than cell wall, breakdown (102). As the breakdown occurred in the apparent absence of bacteria in both studies, enzymes would have to be transported in the conducting tissue to target sites. Pectolytic enzyme production has been reported for strains of $C . m$. ssp. michiganense in vivo $(123)$ and in vitro $(72,123)$. In the latter case, pectolytic activity was detected at low, but not high, $\mathrm{pH}$. The negative report of pectolytic activity by $C$. $m$. ssp. sepedonicum (121) may be due to high pH in the test medium. Patiño-Méndez (123) also detected cellulase activity from infected plants and in vitro, whereas Goto \& Okabe (61) detected cellulolytic activity in vitro by $C . m$. ssp. sepedonicum. Electron microscopy of beans infected with $C$. $f$. ssp. Alaccumfaciens also showed damage to the xylem and decomposition of the middle lamella prior to wilting (39). In the cases cited, however, localized membrane damage cannot be excluded. Yet, in $C$. $m$. spp. insidiosum-infected alfalfa plants, membrane damage was not detected physiologically (see above), and, as with the other cases cited, there was no relationship between the site containing the largest concentrations of bacteria and site of damage (37). An unidentified macerating agent has also been reported from $C$. betae (86). Earlier histological work on the vascular pathogens $C$. m. ssp. sepedonicum, $C$. $m$. ssp. michiganense, $C$. $m$. ssp. insidiosum, $C$. $f$. ssp. flaccumfaciens, and $C$. $f$. ssp. poinsettiae, as summarized by Nelson \& Dickey (113), is generally consistent with the interpretation of enzymatic activity preceding bacterial appearance. The complexities of investigating the degradation of plant cell walls and membranes has been reviewed by Bateman \& Basham (4). 
Another possible pathogenicity factor may be the production of surfactants to promote adhesion to plant surfaces and possibly to enhance entry into plant cells. Thus, it is intriguing that Akit et al (1) found all six $C$. fascians strains tested produced biosurfactants from hexadecane supplemented media, since this bacterium is considered to be principally a surface inhabitant of plants $(41,139)$. However, a strain of $C$. $m$. ssp. insidiosum produced the most surfactant of any bacteria tested. Strains of $C . m$. ssp. michiganense, $C$. $f$. ssp. poinsettiae, $C$. rathayi, and $C$. tritici did not produce any detectable surfactant. Nonpathogens were also tested and produced varying amounts of surfactant, showing that there was no correlation between this property and pathogenicity. Surfactants were detected by reduction of both surface tension and interfacial tension of liquid cultures compared to controls, as well as by critical micelle concentration. Preliminary work, based on pentane extraction, suggested that the surfactants were neutral lipids (1).

The presence of pili has not been reported for phytopathogenic corynebacteria, probably because no one has looked for them. In human and animal corynebacteria, the 11 species examined had pili, with variations in the number per cell and percentage of piliated cells (191). Pili are associated with virulence in some animal pathogens (152). Thus, it would be of interest to learn of their presence or absence and biological significance in the plant pathogens.

Environmental factors sometimes crucially affect disease development. Temperature and humidity can have either synergistic or antagonistic effects on symptom expression, as can pollution. Surprisingly, sulfur dioxide partially inhibited lesion development by $C . m$. ssp. nebraskense in corn without affecting healthy plants (95).

\section{THE ROLE OF NEMATODES IN PLANT DISEASES ASSOCIATED WITH CORYNEBACTERIA}

Certain phytopathogenic corynebacteria are unusual in that nematode transmission is required for characteristic disease development under natural conditions. In these diseases, neither the bacterium nor the nematode alone account for disease, although some growth distortions can occur with either the nematode or sometimes with the bacterium alone. The most dramatic example of such interactions is that of the nematode Anguina agrostis and $C$. rathayi, the only complex that continues to be a serious problem. The association results in both a plant disease, yellow slime, and a neurological animal disease, rye-grass toxicity (5). The disease is characterized by a yellow slime or gumming symptom in the upper parts of plants, especially the inflorescences. Dwarfing, distortion, and yellow seed galls are 
also seen $(5,10)$. At maturity the galls will contain a predominance of either nematodes or bacteria, even though all galls are induced by nematodes (167). Vessels and parenchyma are invaded by the bacteria (10) and several genera of grasses are susceptible (5). Animals feeding on infected galls or grass stubble can experience neurotoxicity; in sheep this includes staggering, collapse, and periods of violent convulsions until death (see 5). The toxic agent(s) can be isolated from infected galls as well as from callus tissue (see preceding discussion).

Other examples of nematode : bacterium interactions are less well studied. Yellow slime or "tundu" disease of wheat requires the presence of Anguina tritici $(11,168)$. As above, this nematode forms a characteristic seed gall, as well as producing distinctive curling leaves with gummy exudates. The nematode acts as a vector for the bacterium, which produces slime. In addition to gumming of leaves, seed production is impaired. Despite its similarity with the annual rye-grass syndrome, there is no evidence of mammalian toxicity. The "cauliflower" syndrome of strawberry (126) also requires the presence of a nematode, Aphelenchoides ritzemabosi, and $C$. fascians for characteristic disease; neither agent alone is sufficient. Unlike $C$. rathayi and $C$. tritici, however, there is ample evidence for $C$. fascians as a pathogen per se $(41,104)$. The ecology of the former species is largely unknown.

Not surprisingly, disease may be more severe in the presence of nematodes that weaken the plant physically or physiologically. Tomato canker, caused by $C$. $m$. ssp. michiganense, is more severe in some plant cultivars in the presence of Meloidogyne incognita (36). Similarly, in a wilt-susceptible cultivar, the number of $C . m$. ssp. insidiosum -infected alfalfa plants may increase in the presence of Ditylenchus dipsaci (68).

\section{GENETICS}

The genetics of plant pathogenic corynebacteria are largely unknown; the same can be said for closely related bacteria. The topic is singled out for discussion because of optimism for the future, since no gene transfer systems have been reported, much less any substantive data.

Plasmids have been found in many species and subspecies $(65,106 ; \mathrm{E} . \mathrm{N}$. Lawson \& M. P. Starr, manuscript in preparation), but there is, as yet, no clear association between their presence and phenotypic properties of pathogenicity, bacteriocin production, drug resistance, or ability to grow on unusual hydrocarbons.

Chromosomal genetic studies are also very limited. There are reports of auxotrophic mutants of $C$. fascians (74) and $C$. $m$. ssp. michiganense (49). The former group obtained mutants with single requirements for glycine, 
aspartic acid, arginine, methionine, creatine, or adenine, whereas Ercolani (49) obtained mutants requiring valine, methionine, or alanine. In each case, the mutants were unable to infect and grow in plants or induce typical symptoms unless the appropriate amino acid or base was supplied exogenously. None of the amino acids had any effect on the infectivity of mutants if these were supplied to the plants 6 days after inoculation, corresponding with a decrease in auxotroph survival. Thus, the absence of bacterial growth in plants could be ascribed to inadequate nutrition, as with other plant pathogenic bacteria (e.g. see 49). It would therefore be of interest to know whether avirulent prototrophic mutants could still attach or whether subsequent steps in the infection process were affected. It would not be surprising to find that, as with many other bacteria, the capsule or cell wall contained necessary virulence factors. However, in one case, extracellular gums seemed to be produced as readily by both a virulent parent and avirulent derivative of $C . m$. ssp. insidiosum (19). Chemical characterization was not done and would be required to detect any differences in gum composition or structure between the strains.

Natural or induced colony morphology or pigment changes have been correlated with loss of virulence in some cases but not in others $(3,17,52$, 74, 92, 135, 142, 160, 179; R. R. Carlson \& A. K. Vidaver, unpublished results). A colorless derivative of $C$. $f$. ssp. poinsettiae (90) was more sensitive to ultraviolet light than was the pigmented parent; similar results have been reported for other bacterial genera.

Freshly isolated bacteria vary in virulence when tested for pathogenicity (e.g. 104, 160, 179). The data suggest that differences in regulation of virulence factors occurs or that more than one gene or pathogenicity factor is involved in disease. It may be that a limited number of nonallelic genes are involved in pathogenicity since no race variation, or specificity associated with plant cultivars, has so far been reported, unlike the case for several Gram-negative pathogens. A decline in virulence of cultures maintained on agar is frequently reported for the $C$. michiganense subspecies (16, $47,110,142,160$ ).

There is still the challenge of finding any means of genetic transfer in these bacteria. The recent report of a plasmid marker in the animal pathogen $C$. diphtheriae (137) is a hopeful sign that successful genetic studies with these bacteria will be as forthcoming as they have been for other Gram-positive bacteria.

\section{BACTERIOPHAGES AND BACTERIOCINS}

Bacterial viruses have been isolated for some of the phytopathogenic corynebacteria. Most of the phages have been reported for members of the taxonomic group belonging to $C$. michiganense: $C . m$. ssp. michiganense 
(46, 183); C. m. ssp. insidiosum (25); and C. m. ssp. nebraskense (146; Y. Shirako \& A. K. Vidaver, manuscript in preparation). There are also reports of phages for $C$. $f$. ssp. Alaccumfaciens (87) and C. rathayi (cited in 10). The characterized phages had relatively long latent periods, low burst sizes, and morphologies similar to the flexous-tailed types reported for $C$. diphtheriae.

It is interesting that no virulent phages have been found for $C . m$. ssp. sepedonicum, with the possible exception of an uncharacterized "transmissible lysin" (169a). This may be due to a type of resistance (immunity), as suggested for some phytopathogenic Erwinia sp. (21), or the particular enriching strain employed; e.g. samples apparently devoid of phage for one enriching strain yielded several phages for another strain of Xanthomonas campestris pv. phaseoli (A. K. Vidaver, unpublished results). It is not known whether phage-like particles associated with $C$. $m$. ssp. sepedonicum are temperate or defective phage, since no biological activity was reported (172).

No evidence of lysogeny has been reported, yet this is a matter of intriguing interest in view of the toxigenic properties carried by temperate phage of $C$. diphtheriae (120).

Bacteriocins are prevalent among this group of corynebacteria (45, 64, 112), but they are not well characterized except for some specificity data and general physical and biochemical properties.

\section{CONTROL}

Broadly speaking, control of plant pathogens can be categorized into chemical control, biological control, use of resistant varieties, cultural practices, and physical control (26). The principal forms of control for phytopathogenic corynebacteria have been sanitation, cultural practices, seed and tuber certification programs (145) that test for the presence of the organism, and plant breeding for resistance. Chemical control has been effectively used only to interrupt the chain of transmission of the potato ring rot bacterium, $C$. $m$. ssp. sepedonicum, by disinfecting equipment, tools, and sacks with formaldehyde or quaternary ammonium compounds $(97,117,144)$. Heat treatment is used commonly to reduce populations of the ratoon stunting bacterium in vegetatively propagated sugarcane (M. J. Davis, personal communication). Biological control is in preliminary stages of development. Echandi (44) found that a nonpathogenic mutant of $C$. m. ssp. michiganense protected tomato plants significantly against subsequent challenge by a pathogenic strain, whereas Oruinbaev (118) reported a $2-8 \%$ reduction of ring rot, with increased germination, plant height, and yield by treatment of tubers prior to planting with an unidentified actinomycete. In vitro antagonists of $C$. m. ssp. insidiosum (69) and $C$. $m$. ssp. nebraskense (62) 
have also been reported, but their significance under natural conditions is unknown.

For microbiologists, there are some curious features to breeding for resistance that should be pointed out. To breed for alfalfa wilt resistance, for example, an otherwise undescribed mixture of wild-type strains of $C . m$. ssp. insidiosum has been used as the inoculum. This mixture is preserved from season to season by freezing roots of infected plants, presumably because pure cultures lose virulence (47). Nevertheless, enduring resistance ( $>25$ years) has been found for this disease. This may be because of the multigenic nature of resistance and the heterogeneity of alfalfa cultivars. This analysis may be valid because resistance is defined as satisfactory if $46 \%$ of the variety is resistant to wilting (see 27). The difficulty of breeding for resistance to alfalfa wilt is compounded by the discovery that the agronomically desirable property of nitrogen fixation can actually decrease in some resistant breeding material (177). In addition, the mechanism of plant resistance is not known in any of the corynebacterial diseases. One possible base from which to begin such analyses is suggested by the finding that sap from resistant tomato (53) is inhibitory to $C$. m. ssp. michiganense.

In analysing resistance, plant breeders have not used quantal responses (i.e. healthy or diseased) as a criterion of resistance. Yet infectivity titrations analyzed this way in tomatoes have potential usefulness in determining not only varieties resistant to the tomato canker bacterium $C$. m. ssp. michiganense $(8,48)$, but also the heterogeneity of resistance $(48)$. Resistance to canker in tomatoes seems to be controlled by multiple genes in complex arrangements (133).

Cultivars resistant to other diseases are not in use for several reasons. Disease-resistant cultivars have been developed for the potentially devastating disease, ring-rot, of potatoes, but have not achieved economic prominence (101). There is concern that such cultivars, if used commercially, may serve as disease carriers because of possible latent infections with the causal bacterium, $C$. $m$. ssp. sepedonicum $(29,70,150)$. Very high populations $\left(10^{6} \mathrm{CFU} / \mathrm{g}\right)$ can be reached without showing symptoms even in susceptible cultivars (7). Field beans resistant to the wilt-inducing $C$. $f$. ssp. flaccumfaciens also have been developed (see 27), but they are not used commercially because the disease does not currently limit production. Germplasm resistant to bacterial mosaic of wheat also has been identified (J. $\mathbf{H}$. McBeath, personal communication); whether or not it will be used in plant breeding depends on disease incidence and severity. In field corn, resistance to Goss's wilt and blight (caused by $C . m$. ssp. nebraskense) was identified and incorporated into commerical varieties soon after the disease was reported (13); the genetic basis of resistance is not yet known. However, as resistant cultivars do not yet yield as well, susceptible cultivars are still 
widely grown. In contrast, popcorn cultivars have shown little resistance (186). In all the cases cited, strains of bacteria that might overcome resistance have not yet been detected. This durability of resistance may be due to the complex nature of resistance, a complex of environmental conditions, or a mutation(s) in the bacteria that has not yet occurred.

There are two reports of induced (as opposed to constitutive) resistance of plants to corynebacteria. Carroll \& Lukezic (18) found that alfalfa leaflets infiltrated with cell suspensions of avirulent strains protected plants inoculated later with pathogenic strains. Even gnotobiotically grown plants preinoculated in the roots with avirulent strains of $C$. $m$. ssp. insidiosum protected against challenge pathogenic strains for up to 5 weeks (18). The protective effect in leaflets and roots was localized at the site of interaction between host cells and avirulent cells of $C . \mathrm{m}$. ssp. insidiosum. The results were specific for the avirulent inducer: Cell-free filtrates, other bacteria, and killed or sonicated virulent cells would not protect. The obvious question is whether specific cell components or living cells are required for this effect, the chemical basis of which is unknown. Ercolani (50), on the other hand, found that a heat-killed wild-type strain of $C$. $m$. ssp. michiganense, as well as Gram-negative bacteria, protected tomato against subsequent challenge better than an auxotrophic derivative. He suggested that some step after attachment to a multiplication site was necessary for induction of the protective response. Whether or not compounds such as phytoalexins (a class of nonspecific antibiotics produced by plants as a response to infection) play any role in resistance needs to be determined. Four different purified phytoalexins were inhibitory at low concentrations to seven Gram-positive bacteria, including $C$. fascians, but not Gram-negative bacteria (57). With Gram-negative bacteria, either localized or systemic-induced resistance can occur (e.g. 58). Obviously this is another area where more research is needed because of the possibility for eventual practical application of induced resistance.

\section{CONCLUDING REMARKS AND PROSPECTS FOR THE FUTURE}

The plant pathogenic corynebacteria are an intriguing group of microorganisms. Many general questions remain unanswered, such as their taxonomic relationship to nonpathogenic coryneforms, their interactions with the environment, their metabolism, and their genetics. Other, more specific questions were addressed in the text. There have been a number of important developments in the last quarter century; these should serve as a basis for future work. 
Finally, it should be mentioned that these bacteria may have useful applications. The copious production of polysaccharides by the plant pathogenic corynebacteria might be exploited, as these may be as useful as xanthan gum, produced by the plant pathogen Xanthomonas campestris pv. campestris. Industrial production of $\mathrm{D}$-alanine by $C$. fascians has been proposed $(188,189)$, as has the production of cytokinins by the same bacterium (181). C. f. ssp. flaccumfaciens might be useful in steroid transformation, as it can hydrolyze steroids (20). The potential usefulness of these bacteria should be evaluated.

\section{ACKNOWLEDGMENTS}

I am indebted to the following for preprints, helpful discussions, or advice: M. J. Davis, S. H. De Boer, K. E. Damann, Jr., D. W. Fulbright, D. C. Gross, J. H. McBeach, M. Sasser, S. A. Slack, E. Stackebrandt, and M. P. Starr. The editorial assistance of R. R. Carlson is gratefully appreciated.

\section{Literature Cited}

1. Akit, J., Cooper, D. G., Manninen, K. I., Zajic, J. E. 1981. Curr. Microbiol. 6:145-50

2. Anderton, W. J., Wilkinson, S. G. 1980. J. Gen. Microbiol. 118:343-52

3. Ark, P. 1951. J. Bacteriol. 61:293-97

4. Bateman, D. R., Basham, H. G. 1976. In Physiological Plant Pathology, ed. R. Heitefuss, P. H. Williams, pp. 316-55. New York: Springer-Verlag

5. Bird, A. F. 1981. In Plant Parasitic Nematades, ed. B. M. Zuckerman, R. A. Rohide, 3:303-23. New York: Academic. $508 \mathrm{pp}$.

6. Bird, A. F., Stynes, B. A. 1977. Phytopathology 67:828-30

7. Bishop, A., Slack, S. A. 1981. Phytopathology 71:861 (Abstr.)

8. Boelema, B. H. 1977. Phytophylactica 9:5-10

9. Bousfield, I. J. 1972. J. Gen. Microbiol. 71:441-55

10. Bradbury, J. F. 1973. In CMI Descriptions of Pathogenic Fungi and Bacteria, No. 376. Kew, England: Commonwealth Mycological Inst. 2 pp.

11. Bradbury, J. F. See Ref. 10, No. 377

12. Brathwaite, C. W. D., Dickey, R. S., 1971. Phytopathology 61:476-83

13. Calub, S. G., Compton, W. A., Gardner, C. O., Schuster, M. L. 1974. Plant Dis. Rep. 58:956-60

14. Carlson. R. R., Vidaver, A. K. 1982. Plant Dis. 66:76-79

15. Carlson. R. R., Vidaver, A. K. 1982. Int. J. Syst. Bacteriol. In press

16. Carroll, R. B., Lukezic, F. L. 1971. Phytopathology 61:688-90

17. Carroll, R B., Lukezic, F. L. 1971. Phytopathology 61:1423-25

18. Carroll, R. B., Lukezic, F. L. 1972. Phytopathology 62:555-64

19. Carroll, R B., Lukezic, F. L., Levine, R. G. 1972. Phytopathology 62:1351-60

20. Chamey, W. 1966. J. Appl. Bacteriol. 29:93-106

21. Chatterjoe, A. K. , Starr, M. P. 1980. Ann. Rev. Microbiol. 34:645-76

22. Collins, M. D., Goodf ellow, M., Minnikin, D. E. 1979. J. Gen Microbiol. 110:127-36

23. Collins, M. D., Goodf ellow, M., Minnikin, D. E. 1980. J. Gen. Microbiol. 118:29-38

24. Collins, M. D., Jones, D. 1980. J. Appl. Bacteriol. 48:459-70

25. Cook. F. D., Katznelson, H. 1960. Can. J. Microbiol. 6:121-25

26. Corbett, J. R. 1978. In Applied Biology, ed. T. H. Coaker, 3:230-330. New York: Academic. 418 pp.

27. Coyne, D. P., Schuster, M. L. 1980. In Advances in Legume Science, ed. R. J. Summerfield, A. H. Bunting, 1:225-33. Kew, England: Royal Botanical Gardens. $667 \mathrm{pp}$.

28. Crombach, W. H. J. 1978. In Coryneform Bacteria, ed. I. J. Bousfield, A. G. Calley, pp. 161-79. London: Academic. $315 \mathrm{pp}$.

29. Crowley, C. F., De Boer, S. H. 1982. Am. Potato J. 59:1-8 
30. Cummins, C. S., Lelliott, R. A., Rogosa, M. 1974. In Bergey's Manual of Determinative Bacteriology, pp. 602-17. Baltimore: Williams \& Wilkins. 8th ed.

31. Daly, J. M. 1981. In Toxins in Plant Disease, ed. R. D. Durbin, pp. 331-94. New York: Academic. 515 pp.

32. Da Silva, G. A. N., Holt, J. G. 1965. J. Bacteriol. 90:921-27

33. Davis, M. J. 1980. Science 210:1365-66

34. De Boer, S. H. 1982. Phytopathology. In press

35. De Boer, S. H., Copeman, R. J. 1980. Am. Potato J. 57:457-65

36. De Moura, R. M., Echandi, E., Powell, N. T. 1975. Phytopathology 65:1332-35

37. Dey, R., Van Alfen, N. K. 1979. Phytopathology 69:942-46

38. Diaz-Mauriño, T., Perkins, H. R. 1974. J. Gen. Microbiol. 80:533-39

39. Dinesen, G. 1978. Proc. Int. Conf. Plant Pathogenic Bacteria, 4th Angers, ed. Station de Pathologie Vegetale et Phytobacteriologie, pp. 929-33. Beaucouze: Inst. Natl. Recherche Agr.

40. Döpfer, H., Stackebrandt, E., Fiedler, F. 1982. J. Gen. Microbiol. In press

41. Dowson, W. J. 1957. Plant Diseases Due to Bacteria. Cambridge: Cambridge Univ. 2nd ed.

42. Dunleavy, J. 1962. Phytopathology 52:8 (Abstr.)

43. Dye, D. W., Kemp, W. J. 1977. NZ J. Agric. Res. 20:563-82

44. Echandi, E. 1975. Proc. Am Phytopath. Soc. 2:56 (Abstr.)

45. Echandi, E. 1976. Phytopathology 66: 430-32

46. Echandi, E., Sun, M. 1973. Phytopathology 63:1398-401

47. Elgin, J. H. Jr., Bames, D. K., Ratcliffe, R. H., Frosheiser, F. I., Nielson, M. W., Leath, K. T., Sorensen, E. L., Lehman, W. H., Ostazeski, S. A., Stuteville, D. L., Kehr, W. R., Peaden, R. N., Rumbaugh, M. D., Manglitz, G. R., McMurtry, J. E. III, Hill, R. R. Jr., Thyr, B. D., Hartman, B. J. 1982. Standard Tests to Characterize Pest Resistance in Alfalfa Cultivars, USDA-ARSNC-19, Revised. In press

48. Ercolani, G. L. 1967. Phytopathol. Mediterr. 6:19-29

49. Ercolani, G. L. 1970. Phytopathol. Mediterr. 9:145-50

50. Ercolani, G. L. 1970. Phytopathol. Mediterr. 9:151-59

51. Fiedler, F., Schäffler, M. J., Stackebrandt, E. 1981. Arch. Microbiol. 129: 85-93

52. Fulkerson, J. F. 1960. Phytopathology 50:377-80
53. Galach'yan, R. M. 1961. In Voprosy Mikrobiologii, ed. A. K. Panosyan, 1:21-40. Erevan: Akad. Nauk Armyan. SSR (In Russian)

54. Gates, J. E., Fisher, R: W., Candler, R. A. 1980. Arch. Microbiol. 127:163-65

55. Gaunt, R. E. See Ref. 39, pp. 973-74

56. George, M., Joseph, T., Potty, V. P., Jayasankar, N. P. 1976. J. Plantation Crops 4:23-24

57. Gnanamickam, S. S., Smith, D. A. 1980. Phytopathology 70:894-96

58. Goodman, R. N. 1980. In Plant Disease, ed. J. G. Horsfall, E. B. Cowling, 5:30517. New York: Academic

59. Gorin, P. A. J., Spencer, J. F. T. 1961. Can. J. Chem. 39:2274-81

60. Gorin, P. A. J., Spencer, J. F. T., Lindberg, B., Lindh, F. 1980. Carbohydr. Res. 313-15

61. Goto, M., Okabe, N. 1958. Nature 182:1516

62. Gross, D. C., Vidaver, A. K. 1978. Appl. Environ. Microbiol. 36:936-43

63. Gross, D. C., Vidaver, A. K. 1979. Phytopathology 69:82-87

64. Gross, D. C., Vidaver, A. K. 1979. Can. J. Microbiol. 25:367-74

65. Gross, D. C., Vidaver, A. K., Keralis, M. B. 1979. J. Gen. Microbiol. 115: 479-90

66. Hale, C. N. 1972. NZ J. Agric. Res. 15:149-54

67. Harrison, M. D., Brewer, J. W., Merrill, L. D. 1980. In Vectors of Plant Pathogens, ed. K. F. Harris, K. Maramorosch. New York: Academic. 467 pp.

68. Hawn, E. J. 1963. Nematologica 9: 65-68

69. Hawn, E. J., Lebeau, J. B. 1962. Phytopathology 52:266-68

70. Hayward, A. C. 1974. Ann. Rev. Phytopathol. 12:87-97

71. Hess, W. M., Strobel, G. A. 1970. Phytopathology 60:1428-31

72. Hildebrand, D. C. 1971. Phytopathology 61:1430-36

73. Ikin, G. J., Hope, H. J., LaChance, R. A. 1978. Can. J. Microbiol. 24:1087-92

74. Jacobs, S. E., Habish, H. A., Dadd, A. H. 1965. Ann. Appl. Biol. 56:161-70

75. Jensen, H. L. .1952. Ann. Rev. Microbiol. 6:77-90

76. Jones, D. 1975. J. Gen. Microbiol. 87: 52-96

77. Jones, D. Soe Ref. 28, pp. 13-46

78. Kado, C. I., Heskett, M. G. 1970. Phytopathology 60:969-70

79. Kampert, M., Strzelczyk, E. 1980. Acta Microbiol. Polonica 29:117-24

80. Kao, J., Blakeney, E. W., Gerencser, M. 
A., Damann, K. E. Jr. 1980. Phytopathology 70:568 (Abstr.)

81. Katznelson, H. 1958. J. Bacteriol. 75: 540-43

82. Keddie, R. M. See Ref. 28, pp. 1-12

83. Keddie, R. M., Bousfield, I. J. 1980. In Microbiological Classification and Identification, ed. M. Goodfellow, R. G. Board. London: Academic. 408 pp.

84. Keddie, R. M., Cure, G. L. See Ref. 28, pp. 47-84

85. Keddie, R. M., Leask, B. G. S., Grainger, J. M. 1966. J. Appl. Bacteriol. 29:17-4.3

86. Kern, H., Naef-Roth, S. 1971. Phytopathol. Z. 71:231-46

87. Klement, Z., Lovas, B. 1959. Phytopathology 49:107-12

88. Komura, I., Yamada, K., Otsuka, S., Komagata, K. 1975. J. Gen. Appl. Microbiol. 21:251-61

89. Kuhn, R., Starr, M. P., Kuhn, D. A., Bauer, H., Knackmuss, H. J. 1965. Arch. Mikrobiol. 51:71-84

90. Kuniswawa, R., Stanier, R. Y. 1958. Arch. Mikrobiol. 31:146-56

91. Kuznetsov, S. I., Dubinina, G. A., Lapteva, N. A. 1979. Ann. Rev. Microbiol. 33:377--81

92. Lacey, M. S. 1939. Ann. Appl. Biol. 26:262-.78

93. Lacey, M. S. 1961. Ann. Appl. Biol. 49:634-44

94. Lachance, R. -A. 1960. Can. J. Microbiol. 6:171-74

95. Laurence, J. A., Aluisio, A. L. 1981. Phytopathology 71:445-48

96. Lelliott, R. A. 1966. J. Appl. Bacteriol. 29:114-18

97. Letal, J. R. 1977. Am. Potato J. 54:405-10

98. Liao, C. H., Chen, T. A. 1981. Phytopathology 71:1303-06

99. Mandel, M., Guba, E. F., 1962. Phytopathology 52:925 (Abstr.)

100. Mandel, M., Guba, E. F., Litsky, W. 1961. Biacteriol. Proc. 1961:61 (Abstr.)

101. Manzer, F., Genereux, H. 1981. In Compendium of Potato Diseases, ed. W. J. Hooker, pp. 31-32. St. Paul, Minn: Am. Phytopathol. Soc.

102. Marte, M. 1980. Phytopathol. Z. 97:252-71

103. Masuo, E., Nakagama, T. 1969. Ann. Rep. Shionogi Res. Lab. 19:121-33

104. Miller, H. J., Janse, J. D., Kamerman, W., Muller, P. J. 1980. Netherlands J. Plant Pathol. 86:55-68

105. Minnikin, D. E., Goodfellow, M., Collins, M. D. See Ref. 28, pp. 85-160

106. Murai, N., Skoog, F., Doyle, M. E.,
Hanson, R. S. 1980. Proc. Natl. Acad. Sci. USA 77:619-23

106a. Murray, T. D. 1982. Phytopathology. In press (Abstr.)

107. Nelson, G. A. 1978. Am. Potato J. 55:449-52

108. Nelson, G. A. 1979. Am. Potato J. 56:71-78

109. Nelson, G. A. 1980. Am. Potato J. 57:595-600

110. Nelson, G. A., Harper, F. R. 1973. Am. Potato J. 50:365-70

111. Nelson, G. A.,Neal, J. L. Jr. 1974. Plant Soil 40:581-88

112. Nelson, G. A., Semeniuk, G. 1964. Phytopathology 54:330-35

113. Nelson, P. E., Dickey, R. S. 1970. Ann. Rev. Phytopathol. 8:259-80

114. Nikitina, K. V., Korsakov, N. I. 1978. Tr. Prikl. Botan. Genet. Sel. 62:13-18 (In Russian)

115. Norris, J. R. See Ref. 83, pp. 1-10

116. Obi, S. K. C. 1981. Appl. Environ. Microbiol. 41:563-67

117. O'Brien, M. J., Rich, A. E. 1979. Potato Diseases. Washington DC: USDA-ARS Agric. Handb. No. 474.79 pp.

118. Oruinbaev, S. 1958. Tr. Inst. Microbiol. Virusol. Acad. Nauk Kaz. SSR 2:51-60 (In Russian)

119. Owens, J. D., Keddie, R. M. 1969. J. Appl. Bacteriol. 32:338-47

120. Pappenheimer, A. M. 1977. Ann. Rev. Biochem. 46:69-94

121. Paquin, R., Lachance, R. -A., Coulombe, L. J. 1960. Can. J. Microbiol. 6:435-38

122. Patil, S. S. 1974. Ann. Rev. Phytopathol. 12:259-79

123. Patiño-Méndez, G. 1967. Studies on the pathogenicity of Corynebacterium michiganense (E.F. Sm) Jensen and its transmission in tomato seed. PhD thesis. Univ. Calif. Davis. 53 pp.

124. Pearson, D. 1971. The biological activity of phytotoxic extracts from Corynebacterium sepedonicum. MS thesis. Univ. Neb. Lincoln. $51 \mathrm{pp}$.

125. Perkins, H. R., Cummins, C. S. 1964. Nature 201:1105-07

126. Pitcher, R. S., Crosse, J. E. 1958. Nematologica 3:244-56

127. Rai, P. V., Strobel, G. A. 1969. Phytopathology 59:47-52

128. Rai, P. V., Strobel, G. A. 1969. Phytopathology 59:53-57

129. Richardson, M. J. 1979. An Annotated List of Seed-Borne Diseases. London: Commonwealth Agric. Bureaux. 320 pp. 3rd ed.

130. Rikard, S. F., Walker, J. C. 1965. Phytopathol. Z. 52:131-44 
131. Ries, S. M., Strobel, G. A. 1972. Plant Physiol. 49:67-84

132. Ries, S. M., Strobel, G. A. 1972. Physiol. Plant Pathol. 2:133-42

133. Russell, G. E. 1978. Plant Breeding for Pest and Disease Resistance. London: Butterworths. 485 pp.

134. Sadowski, P. L., Strobel, G. A. 1973. J. Bacteriol. 115:668-72

135. Saperstein, S., Starr, M. P., Filfus, J. A. 1954. J. Gen. Microbiol. 10:85-92

136. Schaad, N. W. 1979. Ann. Rev. Phytopathol. 17:123-47

137. Schiller, J., Groman, N., Coyle, M. 1980. Antimicrob. Ag. Chemother. 18: 814-21

138. Schleifer, K. H., Kandler, O. 1972. Bacteriol. Rev. 36:407-77

139. Schroth, M. N., Thomson, S. V., Weinhold, A. R. 1979. In Ecology of Root Pathogens, ed. S. V. Krupa, Y. R. Dommergues, pp. 105-56. Amsterdam: Elsevier. $281 \mathrm{pp}$.

140. Schuster, M. L. 1975. Univ. Neb. Agric. Exp. Sta. Res. Bull. 270.40 pp.

141. Schuster, M. L., Coyne, D. P. 1974. Ann. Rev. Phytopathol. 12:199-221

142. Schuster, M. L., Hoff, B., Compton, W. A. 1975. Plant Dis. Rep. 59:101-04

143. Schuster, M. L., Vidaver, A. K., Mandel, M. 1968. Can. J. Microbiol. 14: 423-27

144. Secor, G. A., Lamey, H. A. 1981. Cooperative Extension Service, No. Dakota State Univ., Circular PP-507. 2 pp.

145. Shepard, J. F. Claflin, L. E. 1975. Ann. Rev. Phytopathol. 13:271-93

146. Shirako, Y., Vidaver, A. K. 1981. Phytopathology 71:903 (Abstr.)

146a. Shurtleff, M. C., ed. 1980. Compendium of Corn Diseases, pp. 7-8. St. Paul, Minn: Am. Phytopathol. Soc. 2nd ed.

147. Skerman, V. B. D., McGowan, V., Sneath, P. H. A., eds. 1980. Int. J. Syst. Bacteriol. 30:225-420

148. Slack, S. A., Kelman, A., Perry, J. B. 1979. Phytopathology 69:186-89

149. Slack, S. A., Sanford, H. A., Manzer, F. E. 1979. Am. Potato J. 56:441-46

150. Sletten, A. 1980. Potato Res. 23:111-13

151. Snieszko, S. F., Bonde, R. 1943. Phytopathology 33:1032-44

152. Sokatch, J. R. 1979. In The Bacteria, ed. J. F. Sokatch, L N. Ornston, 3:229289. New York: Academic

153. Spencer, J. F. T., Gorin, P. A. J. 1961. Can. J. Microbiol. 7:185-88

154. Stackebrandt, E., Fiedler, F. 1979. Arch. Microbiol. 120:289-95

155. Stackebrandt, E., Lewis, B. J., Woese, C. R. 1980. Zentralbl. Bakteriol. Parasi- tenkd. Infektionskr. Hyg. Abt. 1 Orig. Reihe C. 1:137-49

156. Starr, M. P. 1949. J. Bacteriol. 57: 253-58

157. Starr, M. P. 1959. Ann. Rev. Microbiol. 13:211-38

158. Steadman, J. R., Bay, R. W., Hammer, M. J. 1979. Proc. Water Reuse Symp., Washington, pp. 2038-45

159. Straley, C. S., Straley, M. L., Strobel, G. A. 1974. Phytopathology 64:194-96

160. Strider, D. L. 1969. No. Carolina Agric. Exp. Sta. Tech. Bull. 193. 110 pp.

161. Strobel, G. A. 1967. Plant Physiol. 42: 1433-41

162. Strobel, G. A. 1970. J. Biol. Chem. 245:32-38

163. Strobel, G. A. 1977. Ann. Rev. Microbiol. 31:205-24

164. Strobel, G., Hess, W. M. 1968. Plant Physiol. 43:1673-88

165. Strobel, G. A., Talmadge, K. W., Albersheim, P. 1972. Biochim. Biophys. Acta 261:365-74

166. Stynes, B. A., Petterson, D. S. 1980. Physiol. Plant Pathol. 16:163-68

167. Stynes, B. A., Petterson, D. S., Lloyd, J., Payne, A. L., Lanigan, G. W. 1979. Aust. J. Agric. Res. 30:201-10

168. Suryanarayana, D., Mukhopadhaya, M. C. 1971. Indian J. Agric. Sci. 41: 407-13

169. Suzuki, K., Kaneko, T., Komagata, K. 1981. Int. J. Syst. Bacteriol. 31:131-38

169a. Thomas, R. C. 1948. Ohio J. Sci. 3: 102-06

170. Thomas, W. D., Graham, R. W. 1952. Phytopathology 42:214

171. Thyr, B. D. 1971. Plant Dis. Rep. 55:336-37

172. Trofimets, L. N., Shneider, Y. I. 1969. Biol. Nauki 12:96-100

173. Van Alfen, N. K., Allard-Turner, V. 1979. Plant Physiol. 63:1072-75

174. Van Alfen, N. K., McMillan, B. D. 1982. Phytopathology 72:132-35

175. Van Alfen, N. K., Turner, N. C. 1975. Plant Physiol. 55:559-61

176. Van Hoof, H. A., Huttinga, H., Knaap, A., Mass Geesteranus, H. P., Mosch, W. H. M., de Raay-Wieringa, D. G. J. 1979. Netherlands J. Plant Pathol. 85:87-98

177. Viands, D. R., Bames, D. K., Forsheiser, F. I. 1980. Crop Sci. 20:699-702

178. Vidaver, A. K. 1967. Appl. Microbiol. 15:1523-24

179. Vidaver, A. K. 1977. Phytopathology 67:825-27

180. Vidaver, A. K. 1980. In Laboratory Guide for Identification of Plant Patho- 
genic E'acteria, ed. N. W. Schaad, pp. 12-16. St. Paul, Minn: Am. Phytopathol. Soc.

181. Vidaver, A. K., Starr, M. P. 1981. In The Prokaryotes: A Handbook on Habitats, Isolation, and Identification of Bacteria, ed. M. P. Starr, H. Stolp, H. G. Triiper, A. Balows, H. G. Schlegel, 2:1879--87. Berlin: Springer-Verlag

182. Vogel, P., Petterson, D. S., Berry, P. H., Frahn, J. L., Anderton, N., Cockrum, P. A., Edgar, J. A., Jago, M. V., Lanigan, G. W., Payne, A. L., Culvenor, C. C. J. 1981. Aust. J. Exp. Biol. Med. Sci. 59:455--68

183. Wakimoto, S., Uematsu, T., Mizukami, T. 1969. Ann. Phytopathol. Soc. Jpn. 35:168--73

184. Wallis, F. M. 1977. Physiol. Plant Pathol. 11:333-342

185. Wilson, V. E., Dunleavy, J. M. 1964. Plant Dis. Rep. 48:453-55
186. Wysong, D., Doupnik, B., Lane, L. 1982. Proc. Ann. Corn Sorghum Ind. Conf., 36th, 1981, In press

187. Yamada, K., Komagata, K. 1972. J. Gen. Appl. Microbiol. 18:417-31

188. Yamada, S., Maeshima, H., Wada, M., Chibata, I. 1973. Appl. Microbiol. 25:636-40

189. Yamada, S., Wada, M., Izuo, N., Chibata, I. 1976. Appl. Environ. Microbiol. 32:1-6

190. Yamada, Y., Inouye, G., Tahara, Y., Kondo, K. 1976. J. Gen. Appl. Microbiol. 22:203-14

191. Yanagawa, R., Honda, E., 1976. Infect. Immun. 13:1293-95

192. Yoder, O. C. 1980. Ann. Rev. Phytopathol. 18:103-29

193. Zagallo, A. C., Wang, C. H. 1967. J. Gen. Microbiol. 47:347-57

194. Zajic, J. E., DeLey, J., Starr, M. P. 1956. Bacteriol. Proc. 1956:116 (Abstr.) 